\begin{tabular}{cc|c}
\hline Tar. Bil. Der. & Tarım Bilimleri Dergisi & Journal of Agricultural Sciences \\
& $\begin{array}{c}\text { Dergi web sayfası: } \\
\text { www.agri.ankara.edu.tr/dergi }\end{array}$ & Journal homepage: \\
& www.agri.ankara.edu.tr/journal
\end{tabular}

\title{
Proteolysis in the Beyaz (White) Cheese Produced From Various Milk
}

Zübeyde ÖNER ${ }^{\mathrm{a}}$, A. Mine SARIDAĞ $\breve{a}^{\mathrm{a}}$

${ }^{a}$ Suleyman Demirel University, Engineering Faculty, Food Engineering Department Isparta, TURKEY

\section{ARTICLE INFO}

Research Article DOI: 10.15832/ankutbd.446454

Corresponding Author: Zübeyde ÖNER, E-mail: zubeydeoner@sdu.edu.tr, Tel: +90 (535) 6156026

Received: 19 August 2016, Received in Revised Form: 07 November 2017, Accepted: 18 January 2018

\begin{abstract}
The aim of this study was to investigate proteolysis development and peptide changes during the storage period of Beyaz (White) cheese which is produced from various types of milk, such as sheep, goat and cow milk. Three types of cheese were produced using goat, sheep and cow milk, and all analyses were performed in duplicate. Proteolytic changes were observed in cheese on the $1^{\text {st }}$ day, $3^{\text {rd }}, 6^{\text {th }}$, and $9^{\text {th }}$ month. The total protein was investigated through using water-soluble nitrogen, soluble nitrogen in $12 \%$ Trichloroacetic acid (TCA), soluble nitrogen in 5\% Phosphotungstic acid (PTA), and free amino acids. Proteolytic changes and peptide formations were observed during maturation by HPLC. While the total protein was $14.33 \%$ in sheep Beyaz cheese on the $1^{\text {st }}$ day, this value decreased during the maturation period and reduced to $6.9 \%$ in the $9^{\text {th }}$ month. These values were 13.55 and 7.95 for cow cheese and $16.30 \%$ and $7.95 \%$ for goat cheese, respectively. The water-soluble protein value increased during the maturation period. The value was $1.41 \%$ in sheep cheese on the $1^{\text {st }}$ day, and increased to $6.24 \%$ in the $9^{\text {th }}$ month. These values were $2.16 \%$ and $4.92 \%$ for goat cheese, and $1.79 \%$ and $8.53 \%$ for cow cheese, respectively. $12 \%$ TCA soluble nitrogen had been $0.211 \%$ at the beginning and was $0.51 \%$ in the $9^{\text {th }}$ month. The ripening value based on $12 \%$ TCA changed between $9.41 \%-47.22 \% .5 \%$ PTA soluble nitrogen changed between $0.075 \%-0.25 \%$. The ripening value based on 5\% PTA changed between 3.34-23.14.

Changes in concentration of total free amino acids during cheese ripening were tracked. In water soluble extracts of cheese, the presence of free amino groups in all ripening stages was detected. It is observed that amino acids and smaller peptides-have concentration significantly $(\mathrm{P}<0.05)$ increased during ripening. The total free amino acid was found as $0.24 \mathrm{mg}$ lysine $\mathrm{g}^{-1}$ in sheep cheese, $0.215 \mathrm{mg}$ lysine $\mathrm{g}^{-1}$ in goat cheese and $0.208 \mathrm{mg}$ lysine $\mathrm{g}^{-1}$ in cow cheese at the end of ripening period.

Keywords: Proteolysis; Sheep milk cheese; Goat milk cheese; Cow milk cheese
\end{abstract}

\section{Farklı Sütlerden Üretilen Peynirlerde Proteoliz}

\section{ESER BILGISII}

Araştırma Makalesi

Sorumlu Yazar: Zübeyde ÖNER, E-posta: zubeydeoner@sdu.edu.tr, Tel: +90 (535) 6156026

Geliş Tarihi: 19 Ağustos 2016, Düzeltmelerin Gelişi: 07 Kasım 2017, Kabul: 18 Ocak 2018

\section{ÖZET}

Bu çalışmada; koyun, keçi ve inek sütlerinden Beyaz peynirler üretilmiş ve depolama süresince farklı sütlerden üretilen peynirlerde proteoliz gelişimi ve peptid değişimlerinin belirlenmesi amaçlanmıştır. 
Bu amaçla; koyun, keçi ve inek çiğ sütlerinden geleneksel olarak Beyaz peynir üretilmiştir. Peynirler 3 tekerrür, analizler 2 paralel halinde yapılmıştır. Peynirlerde 1. gün, 3., 6., 9 ay’da oluşan proteolitik değişimler izlenmiştir. Bu amaçla toplam protein, suda çözünen azot, \% 12 TCA da çözünen azot, \% 5 PTA da çözünen azot, serbest amino asit tayinleri yapılmıştır. Olgunlaşma boyunca görülen proteolitik değişim ve peptid oluşumları RP-HPLC cihazı ile tespit edilmiştir. Koyun Beyaz peynirde 1. gün toplam protein \% 14.33 iken olgunlaşma boyunca bu değerde azalma meydana gelmiş toplam protein 9. ayda \% 6.9'a düşmüştür. İnek peynirinde toplam protein \% 13.55 'den \% 7.95'e keçi peynirinde ise \% 16.30'dan \% 7.95'e düşmüştür. Suda çözünen protein değerinde ise olgunlaşma süresince artış izlenmiştir. Koyun peynirinin suda çözünen protein değeri 1 . günde $\% 1.41 \mathrm{iken}$ bu değer 9 . ayda \% 6.24'e, keçi peynirinde \% 2.16'dan \% 4.92'ye inek peynirinde ise \% 1.79'dan \% 8.53'e çımıştır. \% 12 TCA'da çözünen azot başlangıçta \% 0.211 iken 9. ayda \% 0.51 olarak belirlenmiştir. \% 12 TCA'ya göre olgunlaşma değeri 9.41-47.22 arasında değişmiştir. \% 5 PTA çözünen azot birinci günde 0.075 iken 9 . ayda 0.25 bulunmuştur. \% 5 PTA'ya göre olgunlaşma değeri 3.34-23.14 arasında değişmiştir.

Olgunlaşma süresince toplam serbest amino asit değerleri izlenmiştir. Olgunlaşma süresince peynirin suda çözünen maddeler kısmında serbest amino grupları belirlenmiştir, bu değerler peptit ve amino asitlerin göstergesidir. Olgunlaşma süresince meydana gelen değişim istatiksel açıdan önemli bulunmuştur $(\mathrm{P}<0.05)$. Olgunlaşma sonunda toplam serbest amino asit koyun peynirlerinde $0.24 \mathrm{mg}$ lysine $\mathrm{g}^{-1}$, keçi peynirlerinde $0.215 \mathrm{mg}$ lysine $\mathrm{g}^{-1}$ inek peynirlerinde ise 0.208 mg lysine $\mathrm{g}^{-1}$ peynir olarak saptanmıştır.

Anahtar Kelimeler: Proteoliz; Koyun sütü peyniri; Keçi sütü peyniri; İnek sütü peyniri

(C) Ankara Üniversitesi Ziraat Fakültesi

\section{Introduction}

Beyaz cheese is highly consumed in our country. Various types of milk (sheep, goat, cow) are used to produce Beyaz cheese. Beyaz cheese has various structure, taste and appearance. To involve these features, Beyaz cheese must mature for a certain period of time.

The biochemical reaction is the most important process that shows the maturation of cheese. It occurs as a result of casein hydrolisation by means of plasmins in addition to the effect of rennin enzyme (Fox et al 2000). As a result of hydrolisation, degradation into low-molecular-weight peptides and amino acids occurs through large-and medium-molecular-weight peptides, enzymes and enzymes synthesized by lactic acid bacteria. Proteolysis in cheese is observed through tracking the changes in total nitrogen and nitrogen fractions. During maturation period, proteins which are present in the structure of cheese degrade into polypeptides and amino acids; and depending on the characteristics of amino acids, taste and flavor of cheese vary (Fox et al 1993).

This study aims to analyse the proteolysis rates in cheese which is produced using different types of milk, and in addition to these analyses, to determine peptides formed in the cheese using the HPLC method.

\section{Material and Methods}

\subsection{Material}

Sheep, goat, and cow milk were purchased from different farmers in Isparta region.

\subsection{Cheese-making}

Beyaz cheese was manufactured according to traditional procedures. Beyaz cheese was produced using with sheep, goat and cow milk. Cheese samples were taken on $0^{\text {th }}, 3^{\text {th }}, 6^{\text {th }}, 9^{\text {th }}$ month of ripening. Cheese manufacturing was performed in triplicate and chemical analyses were made duplicate (Öner et al 2006).

Raw milk was clarified and heated to $25-26{ }^{\circ} \mathrm{C}$, and then it was transferred to cheese vats. The milk was coagulated by adding calf rennet in $150 \mathrm{~min}$. The coagulum was cut into cubes $\left(2 \mathrm{~cm}^{3}\right)$ and the curds were allowed to rest in the whey for 5-10 min. The curds were pressed until whey drainage has stopped or decreased to a low level. The weights were removed, cheese were cut $7 \times 7 \times 7 \mathrm{~cm}^{3}$. The blocks were placed in brine $\left(14 \mathrm{~g} 100 \mathrm{~mL}^{-1} \mathrm{NaCl}\right)$ 
for $2 \mathrm{~h}$. The brined blocks were placed in tin can. The cheeses were ripened in the cans at $5-6{ }^{\circ} \mathrm{C}$ for 9 month.

\subsection{Chemical analysis}

Total protein, nitrogen fractions and total free amino acids in the cheese were analyzed. The protein content was measured by Kjeldahl (Gerhardt Vapotest VAP 30 distillation systems, Gerhardt Turbo therm and Turbo digestion systems) according to AOAC method (AOAC 1990).

Water-soluble nitrogenous compounds were separated with the method presented by Kuchroo \& Fox (1982), and water soluble nitrogen ratio was determined by the micro-Kjeldahl method (IDF 1993).

$12 \%$ Trichloroacetic acid soluble nitrogen (TCA-SN) was determined by the standard microKjeldahl method (Polychroniadou et al 1999).

5\% Phosphotungstic acid soluble nitrogen (PTA$\mathrm{SN})$ content of the obtained filtrate was detected by the micro-Kjeldahl method (Polychroniadou et al 1999).

Total amount of free amino acids were performed through the method presented by Folkertsma \& Fox (1992). Absorbance of the sample at $507 \mathrm{~nm}$ which was prepared with Cd-ninhydrin reagent was observed.

\subsection{Water soluble peptides}

The analysis of water-soluble peptides in cheese was carried out with reversed-phase (Shimadzu LC-20 AT series) HPLC and a Zorbax 300 SBC8 monomeric column $(250 \times 9.4 \mathrm{~mm}$ i.d., $6.5 \mu \mathrm{m}$ particle size and $300 \mathrm{~A}^{0}$ pore diameter, Agilent, Waldbronn, Germany). The samples were dissolved

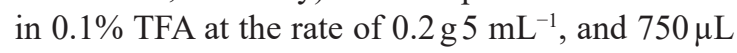
were injected into the HPLC column by filtering it through an $0.45 \mu \mathrm{m}$ diameter filter. The peptides were eluted over a linear gradient from 100 to $0 \%$ solvent A $(0.1 \%$ trifluoroacetic acid in deionized water $)$ in solvent $\mathrm{B}(0.1 \%$ trifluoroacetic acid in $90 \%\left(\mathrm{v} \mathrm{v}^{-1}\right)$ acetonitrile in deionized water) over 80 minutes (Combes et al 2002). The level $214 \mathrm{~nm}$ was detected. Peaks with retention times from 0-40 min were considered to correspond to hydrophilic peptides and peaks with retention times from 40 to $70 \mathrm{~min}$ to hydrophobic peptides (Hayaloğlu et al 2004).

\subsection{Statistical analysis}

Data for experimental cheese varieties were analysed by Anova test through using the general linear model. Differences between means were analysed by Duncan's multiple range test at level of 0.05 using SPSS-software, version 18. This was used in order to comprehend the evaluation of proteolytic changes during storage of each cheese type

\section{Results and Discussion}

\subsection{Total protein}

The total protein contents in cheeses varied depending on the amount of casein in milk and cheese production techniques. The protein rate decreased during ripening period (Table 1). The total nitrogen content, which had been $13.55 \%$ at the beginning of maturation ( 0 days), reduced to $7.93 \%$ at the end of the $9^{\text {th }}$ month. The change in total nitrogen amount in cheese composition is related to protein degradation. It can be explained by the reduction of nitrogenous substances to other compounds (amine, acid, thiol, etc.) (Fox et al 1996). The ripening index value of cow milk cheese reached 107.62 in 9 months. Melting, rancidity, and decomposition were observed in cow cheese during 9 months.

Protein level in the cheese produced from goat milk was between 16.3-7.95\%. This value, which had been $13.28 \%$ at the beginning of ripening index, reached $61.87 \%$ in the $9^{\text {th }}$ month.

Protein level (Table 1) in the cheese produced from sheep milk was between 14.33-6.92. Ripening index values reached $9.78-90.12 \%$. Depending on the metabolic activity in the storage period, the total protein content reduced while the low-molecularweight fractions of nitrogen increased. Some of the nitrogen fractions pass to the pickle, and an increase 
occurs in the concentration of nitrogen fraction dissolved in the brine (Hayaloğlu et al 2002). For the cheese ripened in the brine, water-soluble nitrogen fractions pass to the brine during the storage period until a balance is reached. Proteolysis level in the cheese produced from raw milk varies depending on the rich content of microorganisms. That the ripening index was 90 in the $9^{\text {th }}$ month showed that it increased depending on the microbial flora in raw milk and its proteolytic activity. As a result of the statistical assessment, the change in the protein content during the maturation period was found to be significant $(\mathrm{P}<0.05)$.

Series of biochemical events occur during the ripening period of the cheese. Therefore, the taste, flavor and structure formation occur according to the type of cheese.

In the ripening process, enzyme used for maturation as well as the enzyme in milk, starter cultures, and non-starter bacteria play a role (Fox 1989; Fox et al 1996). In the maturation process, the degradation of lactose, as well as lipolysis and proteolysis events, occur (Mc Sweeney \& Fox 1997). Although the characteristics of Beyaz cheese depend on the acidity and the salt content, final products of lipolysis and proteolysis are effective in the formation of these characteristics (Güler \& Uraz 2004). Many changes were observed in the cheese maturated in the brine within 3 months of production (Hayaloğlu et al 2002). Table 1 reveals the ripening index of the cheese produced from cow milk reached $68 \%$ in 3 months. Cow cheese had the highest proteolysis, and goat cheese had lower proteolysis.

\subsection{Water-soluble protein}

Depending on the proteolysis, water-soluble protein rate increases in a continuous manner during ripening period. This process gives the cheese mature taste and aroma. A part of casein and paracasein in the cheese is degraded with the effect of the enzyme and microorganisms used in the production, and turned into water-soluble substances such as protease-peptone and amino acids. The degradation of protein continues during the maturation process,
Table 1- Protein levels of the Cow, Goat and Sheep cheese

\begin{tabular}{ccccc}
\hline & Months & TP $\%$ & WSN\% & RI \\
\hline \multirow{6}{*}{ Cow } & 0 & $13.55 \pm 0.22^{\mathrm{a}}$ & $1.79 \pm 0.02^{\mathrm{d}}$ & 13.24 \\
& 3 & $8.55 \pm 0.11^{\mathrm{b}}$ & $5.82 \pm 0.07^{\mathrm{c}}$ & 68.05 \\
& 6 & $7.29 \pm 0.45^{\mathrm{c}}$ & $7.10 \pm 0.15^{\mathrm{b}}$ & 97.50 \\
& 9 & $7.93 \pm 0.16^{\mathrm{bc}}$ & $8.53 \pm 0.00^{\mathrm{a}}$ & 107.62 \\
\hline \multirow{6}{*}{ Goat } & 0 & $16.30 \pm 0.19^{\mathrm{a}}$ & $2.16 \pm 0.01^{\mathrm{d}}$ & 13.28 \\
& 3 & $11.06 \pm 0.08^{\mathrm{b}}$ & $2.76 \pm 0.11^{\mathrm{c}}$ & 25.02 \\
& 6 & $9.44 \pm 0.04^{\mathrm{c}}$ & $3.75 \pm 0.13^{\mathrm{b}}$ & 39.69 \\
& 9 & $7.95 \pm 0.08^{\mathrm{d}}$ & $4.92 \pm 0.15^{\mathrm{a}}$ & 61.87 \\
\hline \multirow{6}{*}{ Sheep } & 0 & $14.33 \pm 0.25^{\mathrm{a}}$ & $1.41 \pm 0.12^{\mathrm{d}}$ & 9.78 \\
& 3 & $13.86 \pm 0.43^{\mathrm{a}}$ & $1.97 \pm 0.07^{\mathrm{c}}$ & 14.23 \\
& 6 & $8.76 \pm 0.87^{\mathrm{b}}$ & $5.17 \pm 0.18^{\mathrm{b}}$ & 59.00 \\
& 9 & $6.92 \pm 0.39^{\mathrm{c}}$ & $6.24 \pm 0.0^{\mathrm{a}}$ & 90.12 \\
\hline
\end{tabular}

TP, total protein; WSN, water soluble nitrogen; RI, ripening index. The values in the same column having a different letters differ significantly $(\mathrm{P}<0.05)$. Data were reported as mean \pm standard deviation $(\mathrm{n}=3)$

and increases the amount of the free amino acids and peptides.

In this study, an increase in the water-soluble protein level was observed in parallel to the decrease in the total protein value (Table 1). These values represent the change in the maturation during proteolysis. Özer et al (2002) stated that watersoluble nitrogen values in the Urfa cheese increased during the maturation period. They also stated that these values in the cheese produced from sheep milk were higher than those of the other types of milk at every stage of storage.

\section{3. $12 \%$ TCA soluble nitrogen}

The level of $12 \%$ TCA SN increased during the ripening period (Table 2). This increase indicates the formation of peptides. The difference of peptides from WSN is that the structure of peptides is smaller (peptides consisting of 2-22 amino acids). Immediately after the cheese production, peptide bonds between Phe23 and Phe24 of $\alpha_{\mathrm{s} 1}$-casein are hydrolyzed and formed f1-23 and f24-199 fractions. $\alpha_{\mathrm{s} 1}$-casein (f23) fraction, which has a small chain length, is hydrolyzed quickly by microbial proteinases (peptide 
bonds between Gln9-Gly10 and Gln 13-GLn14), and free amino acids and low-molecular-weight peptides are formed (Fox et al 1996). These elements formed are dissolved in 12\% TCA and are important for the evaluation of proteolysis. Ardo \& Polychroniadou (1999) reported that TCA soluble nitrogenous substances consisted of peptides with 600-15000 Da molecular weight, and these peptides were hydrolysis products of $\alpha_{\mathrm{s} 1}$-casein. Ripening index on the basis of TCA soluble nitrogenous substance provides information about proteolysis at an advanced level. The nitrogen values in 12\% TCA and ripening index changing during the ripening period were given in Table 2. The $12 \%\left(\mathrm{v} \mathrm{v}^{-1}\right)$ TCA-SN contents had the highest levels in the sheep cheese during ripening (Table 2). The increase in the TCA soluble nitrogen levels in the cheese during the maturation period was found to be significant $(\mathrm{P}<0.05)$. These results are similar to the results of Pavia et al (2000b) and Guven et al (2006).

Table 2- Soluble nitrogen fractions and total amino acid concentrations of the cheeses

\begin{tabular}{|c|c|c|c|c|}
\hline & Months & $T C A-S N$ & $5 \% P T A-S N$ & $\begin{array}{c}\text { Total FAA } \\
\left(m g \text { Lysine } g^{-1}\right)\end{array}$ \\
\hline \multirow{4}{*}{ Cow } & 0 & $0.279 \pm 0.009^{d}$ & $0.022 \pm 0.002^{\mathrm{d}}$ & 0.062 \\
\hline & 3 & $0.358 \pm 0.004^{\mathrm{c}}$ & $0.048 \pm 0.001^{\mathrm{c}}$ & 0.116 \\
\hline & 6 & $0.460 \pm 0.003^{\mathrm{b}}$ & $0.064 \pm 0.001^{\mathrm{b}}$ & 0.200 \\
\hline & 9 & $0.5139 \pm 0.004^{\mathrm{a}}$ & $0.070 \pm 0.001^{\mathrm{a}}$ & 0.208 \\
\hline \multirow{4}{*}{ Goat } & 0 & $0.186 \pm 0.005^{\mathrm{d}}$ & $0.070 \pm 0.002^{\mathrm{d}}$ & 0.070 \\
\hline & 3 & $0.320 \pm 0.006^{\mathrm{c}}$ & $0.137 \pm 0.003^{\mathrm{c}}$ & 0.136 \\
\hline & 6 & $0.441 \pm 0.008^{\mathrm{b}}$ & $0.197 \pm 0.004^{\mathrm{b}}$ & 0.174 \\
\hline & 9 & $0.484 \pm 0.009^{\mathrm{a}}$ & $0.233 \pm 0.007^{\mathrm{a}}$ & 0.215 \\
\hline \multirow{4}{*}{ Sheep } & 0 & $0.211 \pm 0.117^{\mathrm{d}}$ & $0.075 \pm 0.003^{\mathrm{d}}$ & 0.107 \\
\hline & 3 & $0.354 \pm 0.007^{\mathrm{c}}$ & $0.090 \pm 0.002^{\mathrm{c}}$ & 0.126 \\
\hline & 6 & $0.468 \pm 0.008^{b}$ & $0.211 \pm 0.004^{b}$ & 0.200 \\
\hline & 9 & $0.518 \pm 0.001^{\mathrm{a}}$ & $0.250 \pm 0.002^{\mathrm{a}}$ & 0.240 \\
\hline
\end{tabular}

TCA-SN, 12\% trichloroacetic acid-soluble nitrogen; PTA-SN, 5\% phosphotungstic acid-soluble nitrogen; FAA, free amino acid. The values in the same column having a different letters differ significantly $(\mathrm{P}<0.05)$. Data were reported as mean \pm standard deviation $(\mathrm{n}=3)$

\section{4. $5 \%$ PTA-SN}

It was reported that the fractions of nitrogen soluble in 5\% PTA in the cheese included peptides smaller than 600-700 Dalton (di-, tri- and tetra- peptides) and amino acids (Mc Sweeney \& Fox 1997; Hannon et al 2003).

The level of nitrogen soluble in phosphotungstic acid in the cheese increased during the ripening period. The $5 \%\left(\mathrm{v} \mathrm{v}^{-1}\right)$ PTA-SN contents had the highest levels in the sheep cheese. It was observed that the ripening time was changed significantly $(\mathrm{P}<0.05)$, according to maturation value 5\% PTA (Table 2). Feeney et al (2001) found that the nitrogen solubility in 5\% PTA in mozzarella cheese increased during the maturation period (70 days). Hayaloğlu (2003) reported that the nitrogen solubility increase in 5\% PTA level during the ripening period of the cheese was due to the solubility in 5\% PTA of the small-molecule peptides and amino acids that emerge during the ripening period.

\subsection{Total free amino acids}

During the ripening of Beyaz cheese, the concentration of total free amino acids increased, no matter whether cheeses were produced from different types of milk. It was observed that this difference observed during the storage period increased the formation of free amino acids in cheese depending on the amount of protease. The 
concentration of total free amino acids on the day 0 was not significant $(\mathrm{P}>0.05)$. It is known that starter bacteria and non starter bacteria are important factors for proteolysis (Hickey et al 2007). At the end of ripening, statistically significant differences were determined in the concentration of total free amino acids between the $0^{\text {th }}$ and $9^{\text {th }}$ month. As a result, during the ripening of Beyaz cheese, the concentration of total free amino acids significantly increased $(\mathrm{P}<0.05)$. The free amino acid ratio in the Beyaz sheep cheese had the total free amino acids at the highest level (Table 2).

It was reported in many studies that additional culture increased the formation of free amino acids (Oneca et al 2007; Wishah 2007; Radeljević et al 2013; Bezerra et al 2016). Similar results were found in Picante cheese and Manchego cheese by using Cd-ninhydrin method for monitoring the proteolysis (Freitas et al 1997; Pavia et al 2000b).

\subsection{Water soluble peptides}

The peptide concentrations of cheese show a sequence according to different molecular weights (Mc Sweeney \& Fox 1997). The mechanism of separation of the peptides released during the ripening period of cheese analysed with the RPHPLC technique. Compatible to this, a fewer hydrophobic molecules give a peak at first, and then the peaks of hydrophobic molecules are observed (Pavia et al 2000a; Hayaloğlu et al 2004; Hesari et al 2006).

The samples of sheep Beyaz cheese in month 0 , $3^{\text {rd }}, 6^{\text {th }}$ and $9^{\text {th }}$ were injected into HPLC, the images of peptide profiles at different wavelengths are given in Figure 1. In the study carried out to choose the appropriate wavelength, it was found that the peaks were detected better at $214 \mathrm{~nm}$.

When the peaks in the RP-HPLC analysis performed to observe peptide formation in sheep Beyaz cheese during the ripening period, hydrophilic

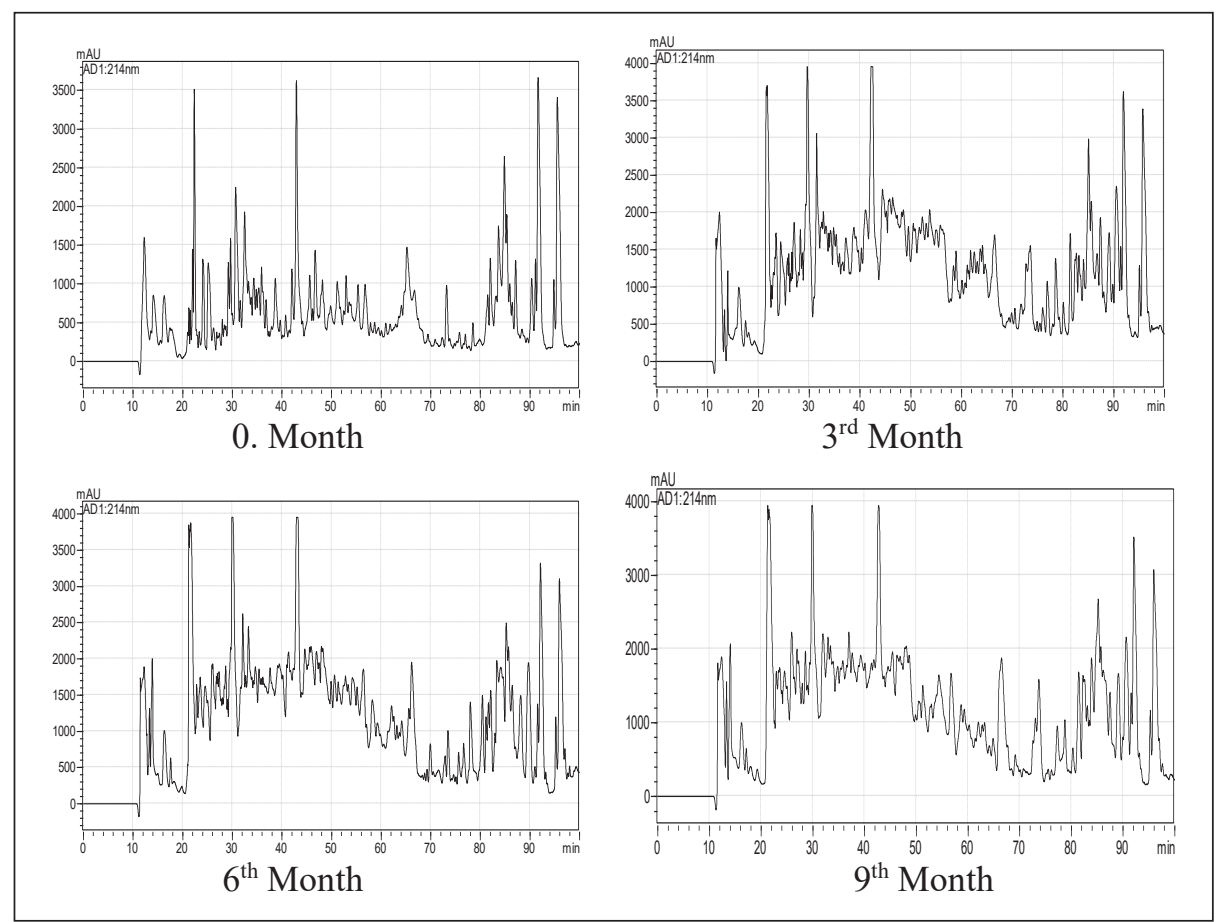

Figure 1- The comparison of chromatogram in the sheep Beyaz cheese during the ripening period (214 $\mathrm{nm})$ 
peptides were observed to be more in 0 month while hydrophilic peptides (with high retention time) and hydrophilic peptides (peaks at early retention time) in the $3^{\text {rd }}, 6^{\text {th }}$ and $9^{\text {th }}$ months were close to each other. Similar results were found for cow and goat cheese (Figure 2-3).

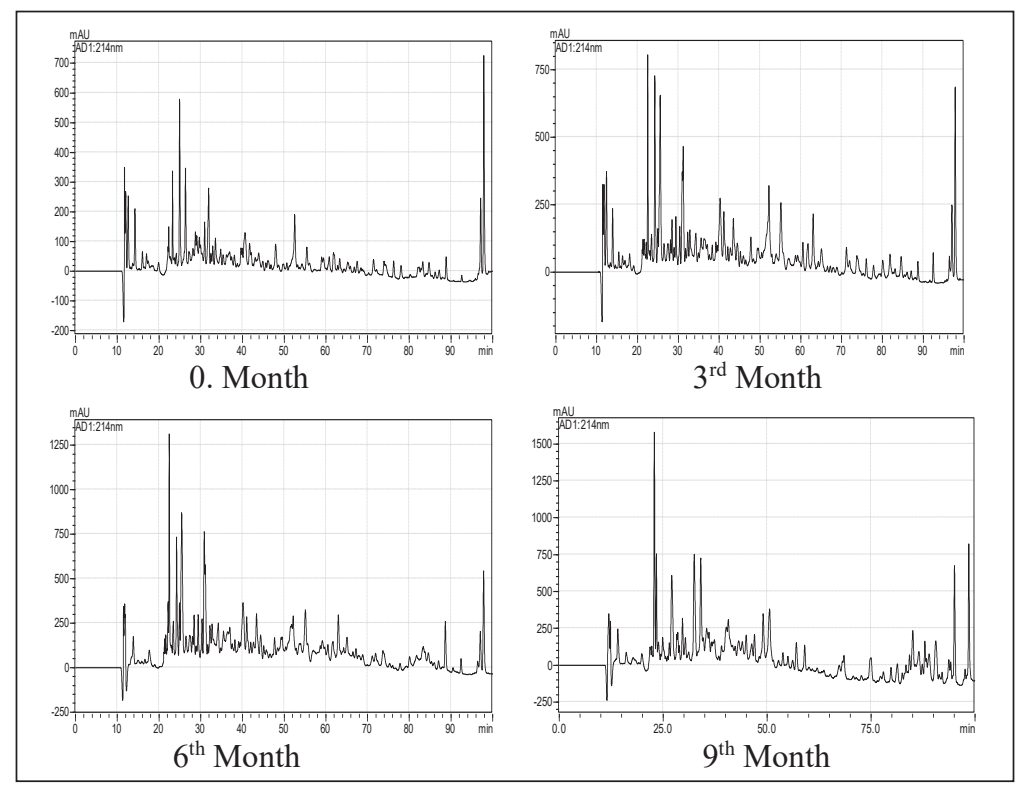

Figure 2- The comparison of chromatogram in the cow Beyaz cheese during the ripening period (214 $\mathrm{nm})$

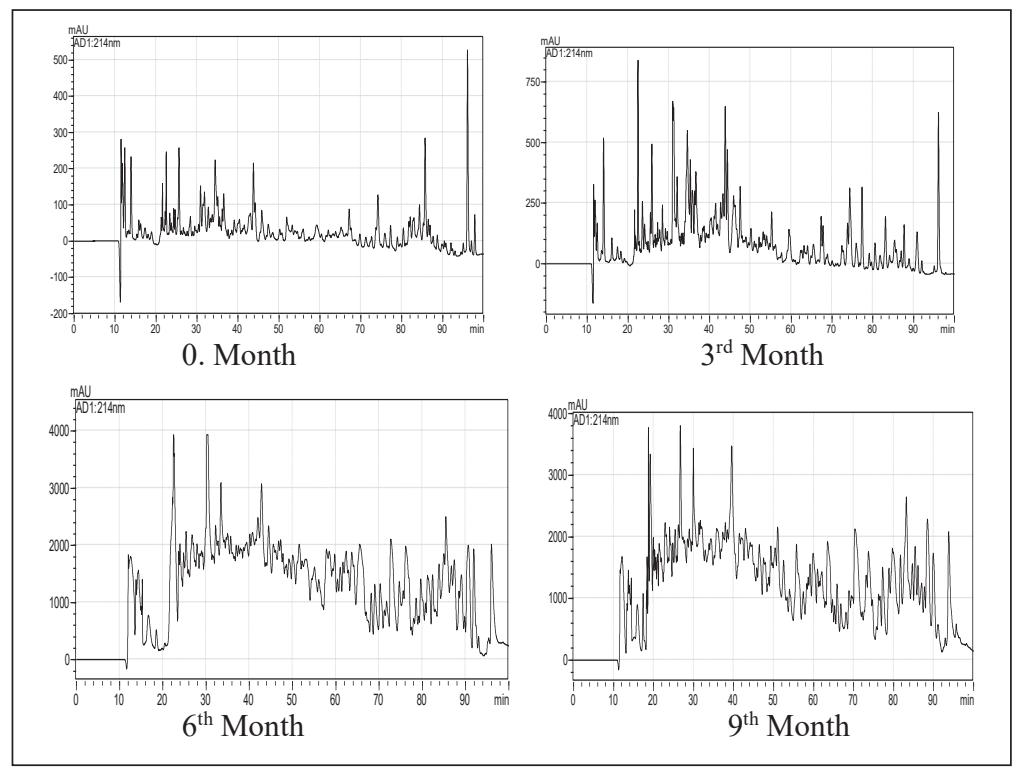

Figure 3- The comparison of chromatogram in the goat Beyaz cheese during the ripening period (214 $\mathrm{nm})$ 
Hayaloğlu \& Karabulut (2013) explored peptides in Civil, Canak, Ezine and Dil cheeses; and the chromatograms of the water-soluble fractions of the cheeses showed that many peptides with early or late retention times. Major qualitative and quantitative differences were observed between the peptide profiles of each cheese variety. Civil cheese had high concentrations of peaks and high levels of soluble nitrogen fractions and both early retention time (hydrophilic) and late retention time (hydrophobic) peptides were determined. However high concentrations of peptides were not detected in Ezine cheese even though this cheese is ripened for at least 6 months. Hayaloglu \& Karabulut (2014) had interpreted the disintegration of peptides probably into amino acids and volatile compounds, such as acids, aldehydes, and alcohols.

Gomez et al (1997) found out that both hydrophilic and hydrophobic peptide concentrations were the same in water soluble nitrogen fractions in Hispanico and semi-hard goat cheese produced from both raw milk and pasteurized milk. Since the sheep Beyaz cheese used in our experiment was produced from raw milk. The concentrations of peptides were affected due to the microflora of raw milk and aminopeptidase activity of non-starter lactic acid bacteria. Feta cheese is similar to Beyaz cheese. Sousa et al (2001) showed that in Feta cheese, most of the peptides from the WSF was originated from $\alpha_{\mathrm{s} 1}$-casein 2 peptides originated from the $C$-terminal of $\beta$-casein and 1 peptide from $\kappa$-casein. Most of the peptides could be explained with the basis of known specificity of chymosin.

\section{Conclusions}

The total protein, water-soluble nitrogen, ripening index, $12 \%$ TCA soluble nitrogen, 5\% PTA soluble nitrogen, and free amino acids analyses were performed in the cheese in order to observe the proteolysis event allowing the formation of peptides. Melting and rancidity occurred in cow and goat cheese in the $9^{\text {th }}$ month. This situation can be seen as normal taking the long ripening period of the cheese into consideration. During the ripening period, the amino acid ratio was observed to increase in all cheese types. It was found out that the shelf life of the cheese produced from cow milk was shorter, rancidity occurred in this type of cheese during the extended storage, and goat and sheep cheeses were more appropriate for storage for longer periods.

Consequently, the cheese made from various types of milk exhibited different protein ratio. Also, it was observed that during the ripening for each cheese has an effect on their proteolysis.

\section{Acknowledgements}

This study was supported by Suleyman Demirel University (SDU) Scientific Research Projects Unit (Project No: 3663 M 13). I would like to thank Suleyman Demirel University Scientific Research Projects Unit for supporting this research.

\section{References}

AOAC (1990). Official Methods of Analysis. Association of Official Analytical Chemists, Washington DC

Ardo Y \& Polychroniadou A (1999). Laboratory Manual for Chemical Analysis of Cheese. Luxembourg Office for Official Publications of the European Communities

Bezerra T A K, Ribeiro de Araujo A R, Santos do Nascimento S, de Matos Paz J, Gadelha C A \& Gadelha T A (2016). Proteolysis in goat "coalho" cheese supplemented with probiotic lactic acid bacteria. Food Chemistry 196: 359-366

Combes C, Paterson E \& Amadòr R (2002). Isolation and 1dentification of low-molecular- weight peptides from Emmentaler cheese. Journal of Food Science 67: 553560

Feeney E P, Fox P F \& Guinee T P (2001). Effect of ripening temperature on the quality of low moisture Mozzarella cheese: 1. Composition and proteolysis. Lait 81: 463-474

Folkertsma B \& Fox P F (1992). Use of the Cd-ninhydrin reagent to assess proteolysis in cheese during ripening. Journal of Dairy Research 59: 217-224

Fox P F (1989). Proteolysis during cheese manufacture and ripening. Journal of Dairy Science 72: 1379-1400

Fox P F, Law J, Mc Sweeney P L H \& Wallace J (1993). Biochemistry of cheese ripening. In: Cheese: Chemistry, Physics and Microbiology (Edited by P.F. Fox), London:Chapman and Hall, pp. 389-438

Fox P F, Wallace J M, Morgan S, Lynch C M, Niland E J \& Tobin J (1996). Acceleration of cheese ripening. Antonie van Leeuwenhoek 70: 271-297 
Fox P F, Guinee T P, Cogan T M \& McSweeney P L H (2000). Fundamentals of Cheese Sciences. Gaithersburg, MD: Aspen Publishers

Freitas A C, Fresno J, Prieto M B, Malcata F X \& Carballo $\mathrm{J}$ (1997). Effects of ripening time and combination of sheep and caprine milks on proteolysis of Picante cheese. Food Chemistry 60: 219-229

Gomez M J, Garde S, Gaya P, Medina M \& Nunez M (1997). Relationship between levels of hydrophobic peptides and bitterness in cheese made from pasteurized and raw milk. Journal of Dairy Research 64: 289-297

Güler Z \& Uraz T (2004). Relationships between proteolytic and lipolytic activity and sensory properties of traditional Turkish Beyaz cheese. International Journal Dairy Technology 57(4): 237-241

Guven M, Yerlikaya S \& Hayaloglu A A (2006). Influence of salt concentration on the characteristics of Beyaz cheese, a Turkish whitbrined cheese. Lait 86: 73-81

Hannon J A, Wilkinson M G, Delahunty C M, Wallace J M, Morrissey P A \& Beresford T P (2003). Use of autolytic starter systems to accelerate the ripening of cheddar Cheese. International Dairy Journal 13: 313323

Hayaloğlu A A (2003). Starter kültür olarak kullanılan bazı lactococcus suşlarının Beyaz peynirlerin özellikleri ve olgunlaşmaları üzerine etkileri. Doktora tezi, Çukurova Üniversitesi Fen Bilimleri Enstitüsü (Basılmamış), Adana

Hayaloglu A A \& Karabulut İ (2013). Primary and secondary proteolysis in eleven Turkish cheese varieties International Journal of Food Properties, 16: $1663-1675$

Hayaloğlu A A, Güven M \& Fox P F (2002). Microbiological, biochemical and technological properties of Turkish White Cheese (Beyaz Peynir). International Dairy Journal 12: 635-648

Hayaloglu A A, Guven M, Fox P F, Hannon J A \& Mcsweeney P L H (2004). Proteolysis in Turkish white-brined cheese made with defined strains of Lactococcus. International Dairy Journal 14: 599-610

Hesari J, Ehsani M R, Khosroshahi A \& Mcsweeney P L H (2006). Contribution of rennet and starter to proteolysis in Iranian UF white cheese. Lait 86: 291-302

Hickey D K, Kilcawley K N, Beresford T P \& Sheehan E M (2007). Starter strain related effects on the biochemical and sensory properties of Cheddar cheese. Journal of Dairy Research 74: 9-17
IDF (1993). Milk Determination of the Nitrogen (Kjeldahl Method) and Calculation of the Crude Protein Content. IDF Standard 20B, Brussels: International Dairy Federation

Kuchroo C N \& Fox P F (1982). Soluble nitrogen in Cheddar cheese: comparison of extraction procedures. Milchwissenschaft 37: 331-335

Mc Sweeney P L H \& Fox P F (1997). Chemical methods for the characterisation of proteolysis in cheese during ripening. Lait 77: 41-76

Oneca M, Ortigosa M, Irigoyen A \& Torre P (2007). Proteolytic activity of some Lactobacillus paracasei strains in a model sheep milk curd system: Determination of free amino acids by RP-HPLC. Food Chemistry 100: 1602-1610

Öner Z, Karahan A G \& Aloğlu H (2006). Changes in the microbiological and chemical characteristics of an artisanal Turkish white cheese during ripening. $L W T$ 39: 449-454

Özer B, Atasoy F \& Akin S (2002). Some properties of Urfa cheese (a traditional white-brined Turkish cheese) produced from bsheep and sheep milks. International Journal of Dairy Technology 55: 94-99

Pavia M, Trujillo A J, Guamis B \& Ferragut V (2000a). Ripening control of salt-reduced Manchego-type cheese obtained by brine vacuum impregnation. Food Chemistry 70: 155-162

Pavia M, Trujillo A J, Guamis B \& Ferragut V (2000b). Proteolysis in Manchego type cheese salted by brine vacuum impregnation. Journal of Dairy Science 83: 1441-1447

Polychroniadou A, Michaelidou A \& Paschaloudis N (1999). Effect of time, temperature and extraction method on the trichloroacetic acidsoluble nitrogen of cheese. International Dairy Journal 9: 559-568

Radeljević B, Mikulec N, Antunac N, Prpić Z, Maletić M \& Havranek J (2013). Influence of starter culture on total free aminoacids concentration during ripening of Krk cheese. Mljekarstvo 63(1): 15-21

Sousa M J, Ardö Y \& Mc Sweene P L H (2001). Advances in the study of proteolysis during cheese ripening. International Dairy Journal 11: 327-345

Wishah R (2007). Peynir üretiminde starter kültüre ek olarak bazı bakteri suşlarının kullanımı ve bunun peynir üzerine etkisi. Yüksek lisans tezi, Hacettepe Üniversitesi Fen Bilimleri Enstitüsü (Basılmamış), Ankara 